\title{
Purification and some characteristics of a calcium-binding protein from Bacillus cereus spores
}

\author{
Yuan-Tay Shyu ${ }^{1}$ and Peggy M. Foegeding ${ }^{1,2 *}$ \\ Departments of Food Science ${ }^{1}$ and Microbiology ${ }^{2}$, North Carolina State University, Raleigh, NC 27695-7624, USA
}

(Received 16 October 1990; revised 13 March 1991; accepted 16 April 1991)

\begin{abstract}
A novel calcium-binding protein has been purified from the dormant spores of Bacillus cereus T. Purity of this protein was verified by SDS-PAGE and reversed-phase HPLC. Its calcium-binding ability was verified by a competitive calcium-binding assay using Chelex-100 resin and ${ }^{45} \mathrm{Ca}$ autoradiography. The protein is heat-stable and is retained by hydrophobic matrices (phenyl-Sepharose) in a calcium-dependent manner. SDS-PAGE and amino acid composition indicate the molecular mass of the protein to be $24 \mathrm{kDa}$.
\end{abstract}

\section{Introduction}

Large amounts of calcium are accumulated in bacterial spores during sporulation. Calcium also plays a role in germination. For example, Bacillus cereus spores and Bacillus megaterium spores with low contents of $\mathrm{Ca}^{2+}$ were unable to germinate in L-alanine and inosine unless $\mathrm{Ca}^{2+}$ was in the medium or a strong electrolyte was present (Rowley \& Levinson, 1967; Sacks, 1972). More than $90 \%$ of the calcium which accumulates during sporulation is released during germination (Rode \& Foster, 1966). $\mathrm{CaCl}_{2}$ can activate $B$. cereus $\mathrm{T}$ spores (Douthit \& Preston, 1985; Nakatani et al., 1985) and calcium can cause germination if the spore coat is removed or weakened. Studies involving stepwise extraction of $\mathrm{Ca}^{2+}$ from labelled spores (Kamat et al., 1985) indicate that part of the spore calcium may be involved in L-alanine-induced germination.

Calcium-binding proteins, which are frequently involved in calcium regulation in eukaryotic cells, have only recently been reported in bacteria, and have been purified only from vegetative cells of Myxococcus xanthus (Inouye et al., 1981) and Streptomyces erythreus (Leadlay et al., 1984). Until this report, dipicolinic acid was the only spore component with documented calcium-binding properties. This study reports a purification scheme for a calcium-binding protein from spores of Bacillus cereus $\mathrm{T}$, and describes some characteristics of the protein and its amino acid composition.

$†$ Present address: Department of Biochemistry and Biophysics, University of California, Davis, CA 95616, USA.

\section{Methods}

Micro-organism. Bacillus cereus T, from the North Carolina State University culture collection, was sporulated at $30^{\circ} \mathrm{C}$ on fortified nutrient agar, harvested, and washed with deionized water as detailed by Johnson et al. (1982). Clean spores were lyophilized and stored at $4{ }^{\circ} \mathrm{C}$.

Crude extract. Dried spores were mixed with two volumes of 250$300 \mu \mathrm{m}$ diameter glass beads and broken in a cell homogenizer (Braun, MSK) while cooling with liquid $\mathrm{CO}_{2}$. Breaking required approximately six pulses of $1 \mathrm{~min}$ each. The breaking efficiency was checked microscopically and by colony counts. The broken powder was suspended in a minimal volume of extraction buffer $[50 \mathrm{mM}-\mathrm{Tris} / \mathrm{HCl}$, pH 7.5, containing $75 \mathrm{~mm}-\mathrm{NaCl}, 1 \mathrm{~mm}$-EDTA, $1 \mathrm{~mm}$-phenylmethylsulphonyl fluoride (PMSF), $1 \mathrm{mM}$-dithiothreitol (DTT), $1 \%(\mathrm{v} / \mathrm{v})$ 2-propanol, $1 \mathrm{~mm}$-benzamide, and $7.5 \mu \mathrm{g}$ pepstatin $\mathrm{A} \mathrm{ml}^{-1}$ ].

Heat treatment. The crude slurry was heated at $90{ }^{\circ} \mathrm{C}$ for 2 min to denature the majority of unwanted spore macromolecules and clarified by centrifugation at $15000 \mathrm{~g}$ for $1 \mathrm{~h}$ at $4{ }^{\circ} \mathrm{C}$. The pellet was resuspended in one-tenth of the original extraction buffer volume and centrifuged again. The supernatant fluids were combined and dialysed at $4^{\circ} \mathrm{C}$ overnight against buffer A $(50 \mathrm{~mm}-\mathrm{Tris} / \mathrm{HCl}, \mathrm{pH} 7.5$, with $5 \mathrm{~mm}$ $\mathrm{CaCl}_{2}, 1 \mathrm{~mm}$-PMSF, 1 mM-DTT, $1 \%$ 2-propanol, $1 \mathrm{~mm}$-benzamidine, and $7.5 \mu \mathrm{g}$ pepstatin $\mathrm{A} \mathrm{ml}^{-1}$ ).

Phenyl-Sepharose chromatography. The dialysed extract (about $600 \mathrm{ml}$ from $28 \mathrm{~g}$ dried spores) was applied to a $1.5 \times 30 \mathrm{~cm}$ phenylSepharose column, pre-equilibrated with buffer $A$ at a flow rate of $1 \mathrm{ml} \mathrm{min}{ }^{-1}$. After the sample was loaded, the column was washed until the $A_{280}$ reached the lowest stable background, then washed to the stable background again with buffer $A$ containing $500 \mathrm{~mm}-\mathrm{NaCl}$. The calcium-binding protein, determined by the Chelex assay (see below), was eluted by washing with buffer $A$ containing $7.5 \mathrm{~mm}$-EGTA but without $\mathrm{NaCl}$ or $\mathrm{CaCl}_{2}$. The peak fractions (about $24 \mathrm{ml}$ ) were pooled and extensively dialysed at $4{ }^{\circ} \mathrm{C}$ against buffer $\mathrm{B}(40 \mathrm{~mm}-\mathrm{Tris} / \mathrm{HCl}$, $\mathrm{pH} \mathrm{8.0)}$. 
DEAE-cellulose chromatography. The dialysed fraction was loaded onto a DEAE-cellulose column $(0.9 \times 30 \mathrm{~cm})$ at a flow rate of $0.8 \mathrm{ml} \mathrm{min}^{-1}$. The column was washed with buffer $\mathrm{B}$, then the protein was eluted with a gradient of $\mathrm{NaCl}(0-0.5 \mathrm{M})$ in the same buffer. Fractions $(3.2 \mathrm{ml})$ were collected and analysed for calcium-binding activity by the Chelex assay.

Hydroxylapatite chromatography. Peak fractions (about $9 \mathrm{ml}$ ) from DEAE-cellulose chromatography were pooled, dialysed against buffer $\mathrm{C}$ (1 mM-sodium phosphate, $\mathrm{pH} 6.8$ ), and applied to a hydroxylapatite column $(0.9 \times 15 \mathrm{~cm})$ previously equilibrated with buffer $\mathrm{C}$ at a flow rate of $0.8 \mathrm{ml} \mathrm{min}^{-1}$. The column was washed with two bed volumes of buffer $\mathrm{C}$ and eluted with a sodium phosphate gradient (1-200 mM). Fractions $(2.4 \mathrm{ml})$ were collected and analysed for calcium-binding activity by the Chelex assay. The calcium-binding fraction was concentrated and extensively washed (dialysed) with $40 \mathrm{~mm}-\mathrm{Tris} / \mathrm{HCl}$ buffer, $\mathrm{pH} \mathrm{7.4,} \mathrm{using} \mathrm{centrifugal} \mathrm{concentration} \mathrm{tubes} \mathrm{(Centricon} \mathrm{or}$ Centriprep, MW cutoff 10000; Amicon). After dialysis, $1 \mathrm{~mm}$ (final concentration) $\mathrm{CaCl}_{2}$ was added to stabilize the proteins which were not used immediately in the calcium-binding assays for $4{ }^{\circ} \mathrm{C}$ storage.

Chelex competitive assay. Calcium-binding activity was routinely checked by the Chelex-100 resin competitive assay (Tokuda $e t$ al., 1987). A slurry of Chelex-100 resin (100-200 mesh, Bio-Rad) was washed extensively with $1 \mathrm{M}-\mathrm{HCl}$, and $40 \mathrm{mM}-\mathrm{Tris} / \mathrm{HCl}, \mathrm{pH} 7 \cdot 4$, then resuspended in $40 \mathrm{~mm}-\mathrm{Tris} / \mathrm{HCl}, \mathrm{pH} 7 \cdot 4$, at a resin-to-buffer ratio of $1 / 10$. While rapidly stirring, $25 \mu \mathrm{l}$ of resin was pipetted into a final reaction mixture volume of $1 \mathrm{ml}$ which contained $10^{6}$ c.p.m. $(0 \cdot 1 \mu \mathrm{M})$

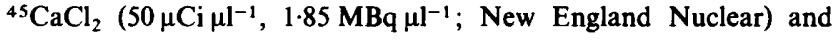
variable concentrations of test substance. After $30 \mathrm{~min}$ of strong agitation at room temperature, the mixture was centrifuged at $3500 \mathrm{~g}$ for $5 \mathrm{~min}$. A $0.1 \mathrm{ml}$ aliquot of supernatant fluid from each reaction mixture was added to $5 \mathrm{ml}$ of Scinti Verse II (Fisher) and subjected to liquid scintillation spectrometry with a Beckman LS 3801 instrument. Under this assay condition, a linear curve of c.p.m. from 6000 to 82000 was obtained by using $0 \cdot 17-17 \mu \mathrm{g}$ purified bovine brain calmodulin (Sigma), while only negligible background counting was given by bovine serum albumin.

Gel electrophoresis. Both denaturing (SDS) and non-denaturing PAGE were carried out on a $15 \%(w / v)$ resolving gel with the discontinuous system described by Laemmli (1970). The gels were stained with Coomassie brilliant blue R-250 (Sigma) or silver stain (Bio-Rad) depending on the protein concentration.

${ }^{45} \mathrm{Ca}$ autoradiography. Calcium-binding ability was verified by autoradiography based on the methods of Maruyama et al. (1984). After non-denaturing electrophoresis, protein was electrophoretically transferred from the gel to nitrocellulose paper $(0.1 \mu \mathrm{m}$, Micron Separation Inc.) at a constant current of $200 \mathrm{~mA}$ for $1 \mathrm{~h}$ at $4{ }^{\circ} \mathrm{C}$ according to the method of Towbin et al. (1979). After electrophoretic transfer, the membrane was washed with $10 \mathrm{~mm}$-imidazole $/ \mathrm{HCl}$, pH $6 \cdot 6$, containing $60 \mathrm{~mm}-\mathrm{KCl}$ and $5 \mathrm{~mm}-\mathrm{MgCl}_{2}$ and incubated at room temperature for $10 \mathrm{~min}$ in the same buffer containing $2.5 \mu \mathrm{M}$ ${ }^{45} \mathrm{CaCl}_{2}$. $\mathrm{Membranes}$ were washed for $5 \mathrm{~min}$ in $50 \%(\mathrm{v} / \mathrm{v})$ ethanol, airdried for $3 \mathrm{~h}$, and exposed to X-ray film (X-Omat AR, Eastman Kodak) for $24 \mathrm{~h}$.

Protein elution. The calcium-binding protein which was localized using the autoradiogram was excised from the membrane and dissolved in a minimum volume of $25 \%(\mathrm{v} / \mathrm{v})$ acetonitrile in $0.1 \mathrm{M}$-ammonium acetate, $\mathrm{pH} 8.9$, for $4 \mathrm{~h}$ at $37^{\circ} \mathrm{C}$. Elution typically required about $0.5 \mathrm{ml}$ of solvent per $\mathrm{cm}^{2}$ of membrane (Montelaro, 1987).

Reversed-phase chromatography. A $2.1 \mathrm{~mm} \times 3 \mathrm{~cm}$ HPLC butyl column (Brownlee Labs) was used for desalting. The elution gradient was $0.1 \%$ trifluoroacetic acid in water and $0.1 \%$ trifluoracetic acid in acetonitrile.
Amino acid analysis. Amino acid composition was determined by the Protein Sequencing Facility at North Carolina State University, using the method of Bidlingmeyer et al. (1984). Salt-free samples from HPLC reversed-phase chromatography were lyophilized and hydrolysed by gas-phase $\mathrm{HCl}$ hydrolysis in a $150^{\circ} \mathrm{C}$ oven for $1 \mathrm{~h}$. After hydrolysis, phenylthiocarbamyl derivatives of the amino acids were formed and analysed by reversed-phase HPLC on a Pico-Tag amino acid analysis column. Molecular mass was determined from the mol \% tyrosine.

\section{Results and Discussion}

\section{Purification of spore calcium-binding protein}

Purification of a novel calcium-binding protein from endospores was carried out using freeze-dried B. cereus $\mathrm{T}$ spores. Lyophilization of the spores enhanced the extraction of calcium-binding protein, avoided formation of sticky bubbles and need for anti-foam, and reduced preparation volumes. Lyophilization also might decrease losses due to protease activity. Disruption of wet spores during purification of small acid-soluble proteins has been shown to allow significant proteolysis (Johnson \& Tipper, 1981; Setlow, 1985). Lyophilized spores were broken and heat treated as described in Methods. Heat treatment was the first step of purification. About $80 \%$ of the calcium-binding activity, as determined by Chelex assay, remained after heat treatment. The heat-treated crude extract was loaded onto a phenyl-Sepharose column. Calcium-binding protein was eluted from phenyl-Sepharose with few contaminants in about the first 1.5 bed volumes by washing with buffer A containing 7.5 mM-EGTA and no salt (Fig. 1). This fraction was further purified using DEAEcellulose chromatography, where a major peak of calcium-binding ability eluted between 0.35 and $0.4 \mathrm{M}$ $\mathrm{NaCl}$. The protein preparation eluted from the DEAEcellulose column was further chromatographed through a hydroxylapatite column. A single peak of calciumbinding activity was resolved between 90 and $120 \mathrm{mM}$ phosphate. This fraction contained a homogeneous protein of molecular mass approximately $24 \mathrm{kDa}$ as determined by SDS-PAGE (Fig. 2). The purity of this calcium-binding protein was also verified by reversedphase HPLC. A single peak eluted at a position corresponding to approximately $61 \%$ acetonitrile (Fig. 3 ). Calcium-binding ability was routinely determined qualitatively during purification by the Chelex competitive assay. Due to the lack of a reliable quantitative activity assay for this novel protein, no precise purification data are available. Approximately $10 \mu \mathrm{g}$ purified calcium-binding protein was obtained from $100 \mathrm{~g}$ wet weight of spores and the yield was about $1 \%$. The detectable calcium-binding capacity of purified calciumbinding protein decreased during storage at $4{ }^{\circ} \mathrm{C}$, 

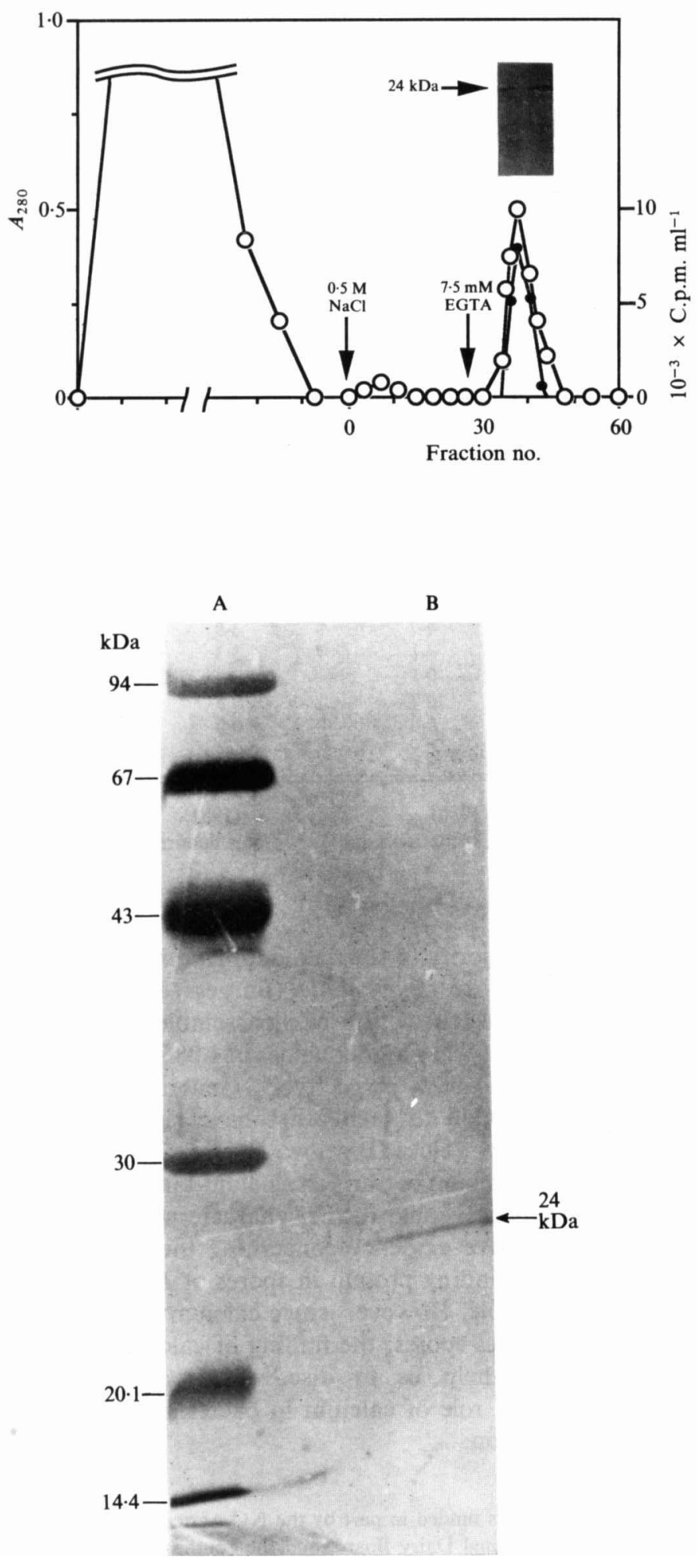

Fig. 2. SDS-PAGE of the calcium-binding protein of B. cereus $\mathrm{T}$ spores. Electrophoresis was carried out on a slab gel of $15 \%$ polyacrylamide. Lane A contains molecular mass markers, from top to bottom: phosphorylase $b$, bovine serum albumin, ovalbumin, carbonic anhydrase, soybean trypsin inhibitor and $\alpha$-lactalbumin. Lane B contains calcium-binding protein (single band denoted by an arrow).
Fig. 1. Elution profile of phenyl Sepharose chromatography. Heat-treated crude preparation was loaded onto a phenyl Sepharose column and $4 \mathrm{ml}$ fractions were collected and assayed for absorbance at $280 \mathrm{~nm}$ $(O)$ and calcium-binding ability (O). The inset shows a silver-stained SDS-PAGE gel $(15 \%$ acrylamide) of fractions 38 and 39 eluted from the affinity column; the apparent molecular mass is indicated on the left.

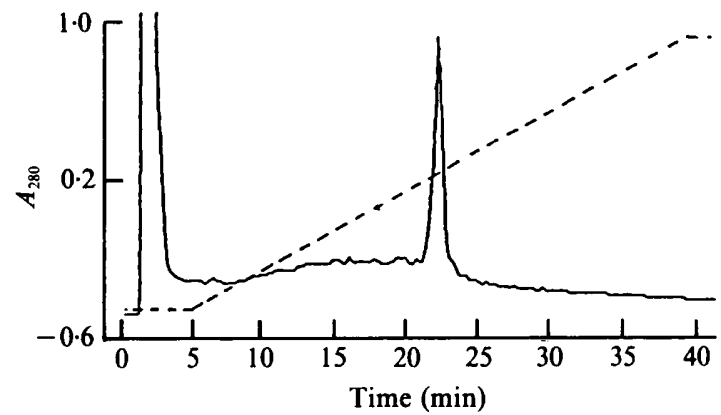

Fig. 3. Elution profile of HPLC reverse-phase chromatography. A $2.1 \mathrm{~mm} \times 3 \mathrm{~cm}$ HPLC butyl column was used for the desalting of calcium-binding protein which eluted from nitrocellulose membranes. The elution gradient (--) was $0-100 \%$ acetonitrile.,$- A_{280}$.

especially in the absence of calcium (data not shown). Instability of purified mammalian duodenal calciumbinding protein and porcine intestinal calcium-binding protein in the absence of calcium during storage has been reported (Randolph \& Strothkamp, 1988).

\section{Calcium-binding ability}

Calcium-binding ability of the purified protein was verified directly by ${ }^{45} \mathrm{Ca}$ autoradiography in the presence of excess amounts of other cations $\left(\mathrm{Mg}^{2+}\right.$ and $\left.\mathrm{K}^{+}\right)$(Fig. 4). The autoradiogram, using protein transferred from a non-denaturing polyacrylamide gel, indicated that one protein with specific calcium-binding ability was present. Migration on the non-denaturing gel appeared close to the calmodulin control. Autoradiography using protein transferred from denaturing (SDS) acrylamide gels was unsuccessful using the $B$. cereus spore calciumbinding protein although it was successful using bovine brain calmodulin (Sigma) as control (data not shown). 


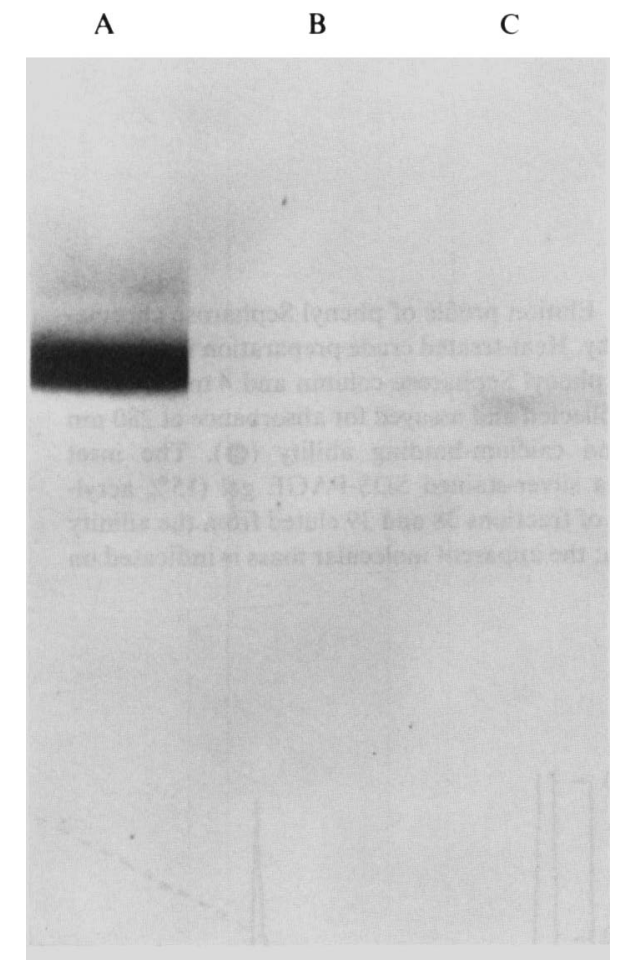

Fig. 4. Autoradiogram showing ${ }^{45} \mathrm{Ca}$ binding to the calcium-binding protein of the $B$. cereus $\mathrm{T}$. Lane $\mathrm{A}$, bovine brain calmodulin $(10 \mu \mathrm{g})$; lane $\mathrm{B}$, bovine serum albumin $(40 \mu \mathrm{g})$; lane $\mathrm{C}$, spore calcium-binding protein (approx $1.5 \mu \mathrm{g}$ ).

\section{Amino acid composition and analysis}

The amino acid composition of the spore calciumbinding protein is shown in Table 1. From the amino acid composition, the molecular mass was determined to be $24 \mathrm{kDa}$ and the protein is composed of 222 amino acid residues. The molecular mass is consistent with that estimated from SDS-PAGE (Fig. 2). The amino acid composition provides information for comparative studies with calmodulin from bovine brain and protein $\mathrm{S}$ from Myxococcus xanthus. Protein S is structurally similar to bovine brain calmodulin, and the calciumbinding domains of these two proteins have a high level of homology (Inouye et al., 1981). None of these three proteins contains Cys residues. The unique trimethyllysine residue present in calmodulin was not determined in the $B$. cereus spore calcium-binding protein. The spore calcium-binding protein has an average hydrophobicity $\left(H \phi_{\text {ave }}\right)$ of $0.90 \mathrm{kcal}(3.77 \mathrm{~kJ})$ per residue and a discriminant function $(Z)$ of 0 according to the calculation methods described by Bigelow (1967) and Barrantes (1975), respectively. Bovine brain calmodulin has similar values of $0.88 \mathrm{kcal}(3.68 \mathrm{~kJ})$ per residue and 0.02 , respectively. Proteins with similar values have been described as soluble non-membrane proteins (Barrantes,
Table 1. Comparison of amino acid compositions of the calcium-binding protein of $B$. cereus $T$ spores, bovine brain calmodulin and protein $S$ from Myxococcus xanthus

\begin{tabular}{|c|c|c|c|c|c|c|}
\hline \multirow[b]{2}{*}{$\begin{array}{l}\text { Amino } \\
\text { acid }\end{array}$} & \multicolumn{2}{|c|}{ Calmodulin* } & \multicolumn{2}{|c|}{ Protein S† } & \multicolumn{2}{|c|}{$\begin{array}{l}\text { Spore calcium- } \\
\text { binding protein }\end{array}$} \\
\hline & $\begin{array}{l}\text { No. of } \\
\text { residues }\end{array}$ & Mol \% & $\begin{array}{l}\text { No. of } \\
\text { residues }\end{array}$ & Mol \% & $\begin{array}{l}\text { No. of } \\
\text { residues }\end{array}$ & Mol \% \\
\hline Asx & 23 & $15 \cdot 5$ & 34 & $16 \cdot 3$ & 24 & $10 \cdot 8$ \\
\hline Thr & 12 & $8 \cdot 1$ & 9 & $4 \cdot 3$ & 5 & $2 \cdot 3$ \\
\hline Ser & 4 & $2 \cdot 7$ & 14 & 6.7 & 10 & $4 \cdot 5$ \\
\hline Glx & 27 & $18 \cdot 2$ & 24 & 11.5 & 43 & $19 \cdot 4$ \\
\hline Pro & 2 & 1.4 & 15 & $7 \cdot 2$ & 4 & 1.8 \\
\hline Gly & 11 & $7 \cdot 4$ & 16 & $7 \cdot 7$ & 22 & 9.9 \\
\hline Ala & 11 & $7 \cdot 4$ & 16 & $7 \cdot 7$ & 23 & $10 \cdot 4$ \\
\hline Val & 7 & $4 \cdot 7$ & 18 & $8 \cdot 6$ & 18 & $8 \cdot 1$ \\
\hline Met & 9 & $6 \cdot 1$ & 1 & 0.5 & 1 & 0.5 \\
\hline Ile & 8 & $5 \cdot 4$ & 13 & $6 \cdot 2$ & 6 & $2 \cdot 7$ \\
\hline Leu & 9 & $6 \cdot 1$ & 15 & $7 \cdot 2$ & 25 & $11 \cdot 3$ \\
\hline Tyr & 2 & 1.4 & 7 & $3 \cdot 3$ & 1 & 0.5 \\
\hline Phe & 8 & $5 \cdot 4$ & 10 & 4.8 & 10 & $4 \cdot 5$ \\
\hline $\mathrm{His}$ & 1 & 0.7 & 0 & $0 \cdot 0$ & 6 & 2.7 \\
\hline Lys & 7 & $4 \cdot 7$ & 8 & 3.8 & 15 & $6 \cdot 8$ \\
\hline Arg & 6 & $4 \cdot 1$ & 7 & $3 \cdot 3$ & 9 & $4 \cdot 1$ \\
\hline TML§ & 1 & 0.7 & - & - & - & - \\
\hline Trp & 0 & $0 \cdot 0$ & 1 & 0.5 & - & - \\
\hline Cys & 0 & 0.0 & 0 & 0.0 & 0 & 0.0 \\
\hline Total & 148 & & 209 & & 222 & \\
\hline
\end{tabular}

* Watterson et al. (1980). † Inouye et al. (1981). † This study. $\S$ TML, trimethyllysine. -, Not determined.

1975). The majority of the calmodulin from many cells appears to be readily soluble (Burgess et al., 1983). However, consistent with it being assembled on the cell surface, protein $\mathrm{S}$ has higher values of $1.08 \mathrm{kcal}(4.52 \mathrm{~kJ})$ per residue and $0 \cdot 25$, respectively. Generally, proteins which are related to each other have similar hydrophobicity index values (Bigelow, 1967).

The small amount of purified calcium-binding protein obtained has prevented further characterization at this time. Conclusive evidence concerning the function of this calcium-binding protein in spores of $B$. cereus $T$ is not yet available. However, since calcium plays a vital role in bacterial spores, the finding of calcium-binding protein may help us to discover more about the regulation and role of calcium in bacterial sporulation and germination.

This project was funded in part by the NC Agricultural Research Service, the National Dairy Board, and the Southeast Dairy Foods Research Center. We thank M. S. Jones and M. E. Kelly for assistance in the amino acid analysis.

Paper number 12530 of the Journal Series of the NC Agricultural Research Service, Raleigh, NC 27695-7643. Trade names in this publication do not imply endorsement by the NC Agricultural Research Service of products named nor criticism of similar ones not mentioned. 


\section{References}

BARRANTES, F. J. (1975). The nicotinic cholinergic receptor: different compositions evidenced by statistical analysis. Biochemical and Biophysical Research Communications 62, 407-414.

Bidlingmeyer, B. A., Cohen, S. A. \& Tarvin, T. L. (1984). Rapid analysis of amino acids using pre-column derivatization. Journal of Chromatography 336, 93-104.

BIGELOw, C. C. (1967). On the average hydrophobicity of proteins and the relation between it and protein structure. Journal of Theoretical Biology 16, 187-211.

Burgess, W. H., Schleicher, M., Van Eldik, L. J. \& Watterson, D. M. (1983). Comparative studies of calmodulin. In Calmodulin and Cell Function, vol. IV, pp. 209-262. Edited by Y. W. Cheung. New York: Academic Press.

Douthit, H. A. \& Preston, R. A. (1985). Activation of Bacillus cereus spores with calcium. In Fundamental and Applied Aspects of Bacterial Spores, pp. 297-307. Edited by G. J. Dring, D. J. Ellar \& G. W. Gould. Orlando, FL: Academic Press.

INouYe, S., Harada, W., Zusman, D. \& INOUYe, M. (1981). Development-specific proteins S of Myxococcus xanthus: purification and characterization. Journal of Bacteriology 148, 678-683.

Johnson, K. M., Nelson, C. \& Busta, F. F. (1982). Germination and heat resistance of Bacillus cereus spores from strains associated with diarrheal and emetic food-borne illness. Journal of Food Science 47, 1268-1271.

JoHNSON, W. C. \& TIPPER, D. J. (1981). Acid-soluble spore proteins of Bacillus subtilis. Journal of Bacteriology 146, 972-982.

Kamat, A. S., Lewis, N. F. \& Pradhan, D. S. (1985). Mechanism of $\mathrm{Ca}^{2+}$ and dipicolinic acid requirement for L-alanine induced germination of Bacillus cereus BIS-59 spores. Microbios 44, 33-44.

LAEMMLI, U. K. (1970). Cleavage of structural proteins during the assembly of the head of bacteriophage T4. Nature, London 227, 680685 .

Leadlay, P. F., Roberts, G. \& Walker, J. E. (1984). Isolation of a novel calcium-binding protein from Streptomyces erythreus. FEBS Letters 178, 157-160.
Maruyama, K., Mikawa, T. \& Ebashi, S. (1984). Detection of calcium binding protein by ${ }^{45} \mathrm{Ca}$ autoradiography on nitrocellulose membrane after sodium dodecyl sulfate gel electrophoresis. Journal of Biochemistry 95, 511-519.

MoNTElaro, R. C. (1987). Protein antigen purification by preparative protein blotting. Electrophoresis 8, 432-438.

Nakatani, T., Tani, K., Imagawa, M., Nishihara, N. \& Kondo, M. (1985). Germination of coat-lacking spores of Bacillus megaterium. Biochemical and Biophysical Research Communications 128, 728-732.

RANDOLPH, A. \& STROTHKAMP, K. G. (1988). Instability of purified 9$\mathrm{kDa}$ porcine intestinal calcium-binding protein in the absence of calcium. Archives of Biochemistry and Biophysics 267, 46-53.

RODE, L. J. \& FOSTER, J. W. (1966). Quantitative aspects of exchangeable calcium in spores of Bacillus megaterium. Journal of Bacteriology 91, 1589-1593.

Rowley, D. B. \& LEvinson, H. S. (1967). Changes in spores of Bacillus megaterium treated with thioglycolate at a low $\mathrm{pH}$ and restoration of germinability and resistance by cations. Journal of Bacteriology 93, $1017-1022$

SACKS, L. E. (1972). Influence of intra- and extracellular cations on the germination of bacterial spores. In Spores $V$, pp. 437-443. Edited by H. O. Halvorson, R. Hanson \& L. L. Campbell. Washington, DC: American Society for Microbiology.

SETLOW, P. (1985). Protein degradation during bacterial spore germination. In Fundamental and Applied Aspects of Bacterial Spores, pp. 285-296. Edited by D. J. Ellar. London: Academic Press.

Tokuda, M., Khanna, N. C. \& Waisman, D. M. (1987). Purification of novel calcium-binding proteins from bovine brain. Methods in Enzymology 139, 68-79.

Towbin, H., Staehelin, T. \& GoRdon, J. (1979). Electrophoretic transfer of proteins from polyacrylamide gels to nitrocellulose sheets: procedure and some applications. Proceedings of the National Academy of Sciences of the United States of America 76, 4350-4354.

Watterson, D. M., Sharief, F. S. \& Vanamam, T. C. (1980). The complete amino acid sequence of the $\mathrm{Ca}^{2+}$-dependent modulator protein of bovine brain. Journal of Biological Chemistry 255, 962 975. 